\title{
Indigenous Ethics and Bionomic Concepts in the New Latin American Constitutions and their Contribution to the Environmental Debate
}

\author{
Prof. Dr. Ronel Alberti da Rosa*
}

DOI: $\quad 10.20399 / P 1982-999 X .2015 v 1 n 2 p p 72-88$

\begin{abstract}
In Latin America, the public sphere has historically conceded a narrow participation range to the indigenous people. Following democratization that changed the continent starting in the 1980s, some Andean countries began to adopt constitutional reforms that enabled the indigenous communities to participate in national decision making. They even went to the point of putting the traditional justice applied by minority groups and the national modern constitutions on the same level. This is particularly the case with Ecuador and Bolivia. In 2008, Ecuador became the first nation to codify and include in its constitution the Rights of Nature. The Ecuadorian ecosystem, thus, became a person of rights, possessing inalienable rights to exist and flourish. Citizens were as well given authority to petition on behalf of the ecosystem. In Bolivia, the New State Politic Constitution, approved in 2009, bestows upon the indigenous groups the right of applying their own justice. This process expresses the accommodation of two juristic zones: that from the Enlightenment positivistic tradition and the autochthonous one. This new legal architecture included regional popular ethical principles that widened the debate about the natural environment and the way the state deals with it. It is the case of concepts like Pachamama (a holistic notion of world) and sumak kawsay (equivalent to that of wellbeing, or even the Good Life). Their revival has diversified the internal juridical landscape by adding an Amerindian perspectivism. This paper will investigate the range of the application of indigenous Ethics and bionomic concepts in multicultural societies, specifically in the case of Latin American countries that have included such elements in their constitutions. It will discuss whether that sort of parallel axiological system could represent a valuable contribution to the global environmental debate.
\end{abstract}

Key Words: Latin America, Ethics, Law, Ecology

\section{Introduction}

The current Latin-American experience is not the only one: in each continent there are countries - like Canada and Malaysia - that also accept more than one jurisdictional possibility to settle conflicts. However, the new constitutions of Bolivia and Ecuador were precursor in recognizing indigenous lands as legal circumscriptions embodied with special status regarding environmental care. There, besides the applicability of indigenous judicial mechanisms, laws that could affect their territories and environmental resources are required to be approved by a referendum that shall be held exclusively by the residents. The new Latin American - constitutions provide a normative framework that links the indigenous movements with new organizations ${ }^{1}$ as

\footnotetext{
${ }^{*}$ PUCRS/Porto Alegre, Brazil

${ }^{1}$ QUIJANO apud ALTMANN (2014).
} 
well as suggests the emergence of some form of post-liberal democracy. ${ }^{2}$ A critical approach to the positivist right in this paper isn't an attempt to diminish rationality and science. It means rather a search for different ways to produce knowledge and more diversified levels of interaction between the economic and political interests of the groups that are involved in the environmental debate. ${ }^{3}$

It is critical to examine the concept of multiculturalism and, analogically, that of multiethnicity. In 1976 the International Covenant on Civil and Political Rights took effect. The Article 27 stipulates:

In those States in which ethnic, religious or linguistic minorities exist, persons belonging to such minorities shall not be denied the right, in community with the other members of their group, to enjoy their own culture, to profess and practice their own religion, or to use their own language. ${ }^{4}$

This covenant entered in the 1990's the juridical architecture of all Latin American countries. However, before approaching the criteria in order to try to determine what an ethnic group is - and how to distinguish ethnic groups -, it shall be noted that the UN chart doesn't possess any strength, due to its lack on power to implement its decisions. As for objectivity, social sciences are prone to override difficulties of differentiation by transferring a concept - in this case, "ethnic group" - into the realm of cultural values. The article 27 of the UN Covenant itself does it implicitly. The same happens with the concept of multiethnicity, which is related to the sharing of a same national space by several ethnic groups. Will Kimlicka, in his book Multicultural Citizenship (1996), suggest browsing the word "culture" in the Oxford Dictionary. The result is that it - the culture - would lie in the uses or in the civil comportment of a group. However, this definition is tautological: it sends the question back to the starting point. According to this definition, even a very uniform and undifferentiated society would exist in a latent multiculturalism condition. In fact, the so called postmodern "tribes", with their craving for differentiation, are ubiquitous in every society. They attest how different culture groups can dynamically cohabit and conflict in a given locus.

Individuals that are immersed in such a multicultural environment, though, maintain and wish to maintain -cultural recognizable signs. These signs constitute the contractual basis on which they interact: on one hand, it provides guaranties for multicultural practice and legitimizes their separateness, and, on the other hand, allows them to coexist with other groups in a space, which can be called the national group. Finally, when it comes to the coexistence of several national subgroups inwardly to frontier marks, it is possible to speak of multinationalism or plurinationalism. Kimlicka (1996) lists criteria for national minorities or "minority nations": present at founding; prior

\footnotetext{
${ }^{2}$ See JONAS, Wolf: Towards Post Liberal Democracy in Latin America? A Conceptual Framework Applied to Bolivia in Journal of Latin American Studies. (http://journals.cambridge.org/action/displayAbstract?fromPage $=$ online $\&$ aid $=8854270 \&$ fileId $=$ S0022216 $\underline{\mathrm{X} 12000843}$ )

${ }^{3}$ See ELLEN and HARRIS apud FOLADORI and TAKS, p. 332

${ }^{4}$ https://treaties.un.org/doc/Publication/UNTS/Volume\%20999/volume-999-I-14668-English.pdf
} 
history of self-government; common culture; common language; governing selves through institutions.

\section{Ecuador}

The traditional Quechua proverb Ama quilla, ama llulla, ama hua! (Don't be lazy, don't lie, and don't steal!) did serve as a triple basis for the Latin American constitutional renewing. The application of that popular phrasing expresses the search of the Constitutional Assemblies of those states for a different formula. That conceptual reconstruction process brought back peculiar forms of thinking of the people of that region and their worldview. It can be seen as a form of archeology of words, which does not seek to dig into the past, but rather the quotidian speaking and acting of the people, as well as their rituality. ${ }^{5}$ Thus, instead of just permitting to the Quechua and Aymara communities to cultivate their ancestral practices, it went farther, and included some genuine popular ethical values in the constitutional texts. This move inverted the judicial architecture's traditional course: it points not always from the universal towards the particular, but sometimes also from the particular (the communitarian) towards the universal (the law). This kind of jurisdictional perspectivism was hitherto unprecedented in the continent.

Another concept to be examined is that of sumak kawsay, equivalent to that of wellbeing, or even Good Life. In Quechua, Sumak means ideal, perfection, whereas kawsay means life. As a moral principle, this Andean "plenitude of life", thus, would correspond to the classical Greek formula that linked $e u+$ bios. The eubiotic apprehension of Ethics is a common feature to many Andean communities. Pablo Dávalos, Ecuador's former Economy vice-minister explains how it should be understood:

It isn't merely a naive way of life aiming to harmonize human beings and nature: the indigenous ethics of the Good Life is an alternative to the capitalist way of goods production, distribution and consuming. It is, above all, part of the narrative of 'resistance and mobilization'.

Hence, the Good Life regulates a different form of relationship between society and nature, whereby the egoist individuality is expected to subject itself to the principle of social responsibility and ethical commitment. According to this world view, Nature is recognized as a core element of human sociability. ${ }^{6}$

The Good Life will be covered in detail in a next section of this paper.

Now to the Preamble of Ecuador's new constitution and the reach of its phrasing: the two first words, NOSOTRAS Y NOSOTROS (We women and men), el pueblo soberano de Equador (...the sovereign people of Ecuador... etc), utilizes the first person plural, the "we" of Spanish; the phrase was constructed using not only the masculine form - in Spanish there is also a feminine "we" form, which is the NOSOTRAS that introduces the

\footnotetext{
${ }^{5}$ KOWII, Ariruma: El Sumak Kawasay, 2. http://www.un.org/esa/socdev/unpfii/documents/E1\%20Sumak\%20Kawsay-ArirumaKowii.pdf ${ }^{6} \mathrm{http}: / / \mathrm{www}$. ihuonline.unisinos.br/index.php?option=com content $\&$ view $=$ article $\&$ id $=3436 \&$ secao $=340$
} 
Preamble. This expression is, at least, a novelty in a continent that is considered a judicial misogynistic stronghold. ${ }^{7}$

In the new phrase, the Preamble alludes to the immemorial roots of the pre-Columbian peoples of that region and recognizes their multiethnic character: RECONOCIENDO nuestras raices milenarias, forjadas por mujeres y hombres de distintos pueblos... (RECOGNIZING our age-old roots, wrought by women and men from various peoples...). It addresses, thus, not only women and men (highlighting their gender differences), but women and men of different origins.

The Preamble of Ecuador's new constitution has been constructed according to a plan that enlarges gradually the protection status that the state bequeaths individuals; each line takes a new category in custody:

(1) gender;

(2) different peoples;

(3) world.

The third stage widens decisively the moral sphere and the beings the state commits to protect. It mentions the world, which is the environmental space that not only embraces everything but also $i s$ itself the central player in the ecobiotic indigenous mentality. This idea permeates the whole document. In this section the-constitution - which is written in Spanish - utilizes the vocable Pachamama: this word comes from the extinct kolla language, which was spoken in the Inca Empire. It corresponds to the higher authority exerted by Nature. The rest of the paragraph continues: CELEBRANDO a la naturaleza, la Pachamama, de la que somos parte y que es vital para nuestra existencia... (CELEBRATING nature, the Pachamama (Mother Earth), of which we are a part and which is vital to our existence...).

\section{The Pachamama}

Etymologically, Pachamama refers neither to earth nor to mother. It encompasses a semantic group that denotes a period of time, space and earth as well.. AditionallyMama, which expresses authority, isn't necessarily feminine. The recovery of the Pachamama concept - it had almost disappeared even among the Andean communities - lights a beacon that illuminates goals that are analogue to those of the international environmental movement. And not only that: as stressed by Renaud Lambert in his paper "The Spirit of Pachamama", this trend has been welcomed also by the industrial powers. The goal of the sustainable development movement is to rehabilitate the relationship between man and nature as one of the pillars of modern society. ${ }^{8}$

Paul Radin (Primitive Man as Philosopher) affirmed that the link between man and nature was the primordial cause of the mutual influence both had on each other: Nature cannot resist man, man cannot resist nature. A purely mechanistic conception of life is thus unthinkable (RADIN, 274). It parallels the role of Pachamama in the Andean

\footnotetext{
${ }^{7}$ In Latin America, women have historically been a group with restricted civil representation. In Brazil, for example, the expression 'honest woman' - as a denomination for non adulteress female citizens - has been withdrawn only recently from the Penal Code (Lei 11.106/2005).

${ }^{8}$ See LAMBERT, Renaud, 28.
} 
culture (and that of $\kappa o ́ \sigma \mu o \varsigma$ - cosmos - in the Greek holistic understanding of life). The idea of a universal structure, which includes microcosms and macrocosms ${ }^{9}$ appears clearly in all these attempts to define the place wherein mankind can live and thrive without sustainably.

\section{Bolivia}

In 2009, the Republic of Bolivia approved a new constitution and changed the name of the country into Plurinational State of Bolivia. It also followed Ecuador in recognizing the ecosystem as a holder of rights. The Bolivian president Evo Morales, himself descendent of the Aymará ethnic group, created a Ministry of Mother Earth and approved a Law of the Rights of Mother Earth ${ }^{10}$ which recognized the judicial personhood of the Pachamama (the Earth). From then on, it became titular of seven fundamental rights, that ultimately puts Earth and humans on the same level:

- To life: It is the right to the maintenance of the integrity of life systems and natural processes which sustain them, as well as the capacities and conditions for their renewal

- To the Diversity of Life: It is the right to the preservation of the differentiation and variety of the beings that comprise Mother Earth, without being genetically altered, nor artificially modified in their structure, in such a manner that threatens their existence, functioning and future potential

- To water: It is the right of the preservation of the quality and composition of water to sustain life systems and their protection with regards to contamination, for renewal of the life of Mother Earth and all its components

- To clean air: It is the right of the preservation of the quality and composition of air to sustain life systems and their protection with regards to contamination, for renewal of the life of Mother Earth and all its components

- To equilibrium: It is the right to maintenance or restoration of the interrelation, interdependence, ability to complement and functionality of the components of Mother Earth, in a balanced manner for the continuation of its cycles and the renewal of its vital processes

- To restoration: It is the right to the effective and opportune restoration of life systems affected by direct or indirect human activities

\footnotetext{
${ }^{9}$ It is clearly manifest that the dynamic principle is here fundamental. The static principle is definitely only the temporary shell, the body, doomed to early extinction and decay. Also, there is the inability to express the psychical in terms of the body; the psychical must be projected upon the external world. The Ego, in other words, cannot contain within itself both subject and object, although the object is definitely conditioned by and exists within the perceiving self. Thus we have an Ego consisting of subject-object, with the object only intelligible in terms of the external world and of other Egos. This does not in any sense, of course, interfere with the essential dualism of primitive thought but it does imply a tie between the Ego and the phenomenal world foreign to that which we assume. And this connection is very important, for it takes the form of an attraction, a compulsion. Nature cannot resist man, man cannot resist nature. A purely mechanistic conception of life is thus unthinkable. (RADIN, 274) ${ }^{10} \mathrm{http}: / /$ ucordillera.edu.bo/jdownloads/BoletinesComunicados/decreto1696.pdf
} 
- To live free of contamination: It is the right for preservation of Mother Earth and any of its components with regards to toxic and radioactive waste generated by human activities. ${ }^{11}$

That equivalence started a process that is still ongoing in Bolivia. The 411 articles of the new constitution mark the transition from a Unitarian state into a Plurinational one. However, Bolivia is not an isolated case: after living a great part of the twentieth century mired in military dictatorships, South America initiated democratic changes in the middle of the 1980s. A core polemic emerged in the wake of this transformation: it concerned the essence of what the South American states should be and represent. The constitutional reforms triggered by this new legal approach gave voice and civil rights to segments of the society that had been marginalized.

\section{Rights for all... and for everything}

The Declaration of the Rights of Man and of the Citizen was one of the leading documents produced by the French Revolution of 1789 that helped to strengthen the Enlightenment's ideal of rationality and anthropocentrism. It spread, at the same time, a world view that widened the secession of culture and nature. The Declaration represented the majority's certification of the bourgeoisie - a revolutionary class (according to Marx) that would soon become reactionary. The burgher civilization bolstered, authorized by that ideology, the process of domination of nature - a process which became constituent of itself and had been already legitimized by passages of the Old Testament ${ }^{12}$ - up to the point of damaging the balance of life on the planet.

The new Latin American national constitutions are undergoing a shift from their initial liberal stage. During the first period of the Industrial Revolution, only the rights of homo economicus were guaranteed. The inner society power balance evolved, however, to a new paradigm, in order to include the rights of a larger moral community. This new paradigm tries to mediate the coexistence of three players that interact and establish a sort of moral pyramid: rational animals, irrational animals and the Pachamama. The Pachamama, as a kind of indigenous pantheist being, includes humans, their culture and science and all elements of the natural world, i.e. the non-rational world. The Pachamama has the role of regulating the communal life of cultural as well as noncultural elements. Each player, however, has distinct tendencies: the cultural elements push on a civilization process that acts according to a domination logic - it struggles to overcome everything that is non-rational in an Enlightenment way ${ }^{13}$; the non-cultural elements tend to remain in a raw state - within the non-cultural realm, though, the living

\footnotetext{
${ }^{11}$ http://www.ftierra.org/ft/index.php?option=com_content\&view=article\&id=4288:rair\&catid=152:cc\&It emid $=210$

${ }^{12}$ Then God said, 'Let us make humankind in our image, according to our likeness; and let them have dominion over the fish of the sea, and over the birds of the air, and over the cattle, and over all the wild animals of the earth, and over every creeping thing that creeps upon the earth.' So God created humankind in his image, in the image of God he created them; male and female he created them. God blessed them, and God said to them, 'Be fruitful and multiply, and fill the earth and subdue it; and have dominion over the fish of the sea and over the birds of the air and over every living thing that moves upon the earth (Genesis, I, 26).

${ }^{13}$ The clash of both tendencies configures an aporetic situation, since each party depends also of the other in order to exist. The School of Frankfurt depicted it as the motor of history, short as the tragedy of the domination of nature by the human kind.
} 
beings perform a fierce struggle for life, which remains internal to the system, and don't challenge the environmental status quo. The Pachamama stands between as well constitutes them- in short, it doesn't privilege any link of the chain because it doesn't work according to a teleological pattern, i.e. there is no goal to be achieved, hence there is no purpose in privileging any link of the chain.

This process has analogies to that proposed by the first English Utilitarianists in the 18th century, now in a broader way. Jeremy Bentham, in his An Introduction to the Principles of Morals and Legislation, widened the narrow moral community of his time, proposing that "The question is not, Can they reason? nor Can they talk? but, Can they suffer?"14 Thus, sentience, the capacity of feeling pleasure or pain, begins to occupy with rationality the core of the Western moral architecture. The controversial point regarding the limits of human suffering in comparison to that of non-rational animals remains an open question ${ }^{15}$. The Bolivian Mother Earth legislation and its Mother Earth Ministry aim to protect all elements that exist in the Pachamama, sentient or not, living or not, thus rivers, stones and valleys - the complete geographic display - are counted as well.

The classical concept of the Good Life, is the attempt to lead by means of reflecting on human action in the world the best life that a human being can. The origin of the Good Life idea can be traced to the Classical Greek philosophy, where it appears linked to

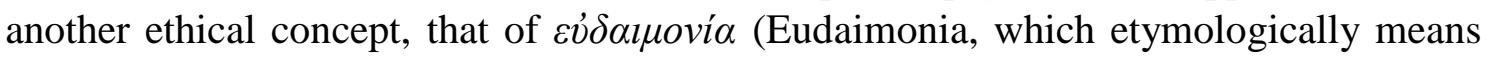
Good Spirit). In Aristotle's Ethics, a desirable life can be achieved through the rational understanding of what living well is:

Verbally there is a very general agreement; for both the general run of men and people of superior refinement say that it is [eudaimonia], and identify living well and faring well with being happy; but with regard to what [eudaimonia] is they differ, and the many do not give the same account as the wise. For the former think it is some plain and obvious thing like pleasure, wealth or honour... [1095a17] ${ }^{16}$

In modern Western societies, the understanding of Good Life is oft narrowed and linked with the experience of property. Nowadays, globalization and the almost unlimited expansion of consumerism appear as the practical manifestation of that linkage. ${ }^{17}$ Actually, the Good Life transcends the mere satisfaction of subjective wishes and access to services. ${ }^{18}$ Hence, it cannot be understood as a link in the chain development $=>$ consume $=>$ happiness $=>$ development

\footnotetext{
${ }^{14}$ BENTHAM apud SINGER, Peter: Practical Ethics, Cambridge, 1979, Chap. 3

${ }^{15}$ Human thinking mechanisms - like memory and fantasy - would allow them to project themselves into the past or the future, placing thus people's capacity to rejoice or suffer above that of non-rational animals and holding rational animals to a higher moral standard.

16 ARISTOTLE, also David Ross, Lesley Brown (1980). "The Nicomachean Ethics". Oxford University Press. Retrieved 2010-06-05.

${ }^{17}$ GORDON Cesar: Bem Viver e propriedade: o problema da diferenciação entre os Xikrin-Mebêngôkre (Kaypó) in MANA 20(1), 2014, p. 95.

${ }^{18}$ See VITERI by ALTMANN (2014, p. 87)
} 
The perspective character of indigenous Ethics could again provide alternatives to that vicious cycle. However, a simple inversion of paradigms would be just as wrong: a shift demanding an idealized indigenous dealing with nature would be a hurdle rather than a virtue. It could degenerate into paralysis and conservatism, when the point is to diversify alternatives for better human development. ${ }^{19}$ The advantage of the perspectival option lies rather in its multiplicity than in a supposed new rightness.

Good Life (or wellbeing) as an ethical benchmark is akin rather to virtue ethics - in an Aristotelian pattern - than to a deontological Kantian moral. Deontology stresses the duty to do or the prohibition against doing something and follows the Enlightenment's moral doctrine by means of recognizing solely rational grounds for human actions. On the other hand, virtue ethics stresses the inner qualities of a single person, and focuses on freedom of action. Similarly, the Amerindian Good Life encompasses virtues like prudence, fortitude, temperance etc.

In the 1950s Western moral philosophy had already begun to recover the Aristotelian concept of virtue ethics. After Elisabeth Anscombe (Modern Moral Philosophy, 1958), a series of works approached the issue, for example Michael Stroker's The Schizofrenia of Modern Ethical Theories (1976), Alasdair MacIntyre's After Virtue (1981) and Paul Ricoeur's Oneself as Another (1990). They are all pervaded by the attempt to conciliate Ethics and individuality. A worthy precursor to that trend was Theodore Adorno's Minima Moralia - Reflections from Damaged Life (1951). Adorno attempted to get over the positivistic strain of judicial regulation through the aphorismatic form of his writing, which has no hints of duties or obligations, but rather depicts the inner psychological condition of the individual who is forced to live in mass society.

\begin{abstract}
The more that civilization preserves and transplants unspoiled nature, the more implacably the latter is controlled. One can afford to encompass ever greater units of nature and to leave the interior of such tracts seemingly intact, while previously the selection and domestication of particular pieces still testified to the necessity of conquering nature. ${ }^{20}$
\end{abstract}

An eudaemonic analogue to the concept of Good Life can be found among several indigenous cultures, demonstrating it is not exclusive to the Incas' descendents: it appears in the form of Sumak Kawsay in the Quechua language, it is known as Suma Qamaña among the Aymarás people and as Teko Porã in the Guarani language. ${ }^{21}$ The Guaranis live in the flatlands of Paraguay, Argentina and Brazil; their myth of the 'Land without Evil', the Yvy Mará'ey, tells of the utopian coexistence of mankind and nature. The following paragraph of Max Horkheimer's The Revolt of Nature is illustrative regarding this subject:

He (rationality) reifies the subject. Yet the more all nature is looked upon as 'quite a mess of miscellaneous stuff' ('mess' doubtless only because the structure of nature does not correspond to human use), as mere objects in relation to human subjects, the more is the once supposedly autonomous

\footnotetext{
${ }^{19}$ FOLADORI and TAKS, p. 335

${ }^{20} \mathrm{http}: / /$ members.efn.org/ /dredmond/MM2.html

${ }^{21}$ For the history of the revival of the concept of Good Life in the Andean region, see ALTMANN, Philipp: Good Life As a Social Movement Proposal for Natural Resource Use: The Indigenous Movement in Ecuador in Consilience: The Journal of Sustainable Development (http://www.consiliencejournal.org/index.php/consilience/article/viewFile/340/195).
} 
subject emptied of any content, until it finally becomes a mere name with nothing to denominate. The total transformation of each and every realm of being into a field of means leads to the liquidation of the subject who is supposed to use them. This gives modern industrialist society its nihilistic aspect. Subjectivization, which exalts the subject, also dooms him. ${ }^{22}$

As demonstrated above, the new constitutions of Ecuador and Bolivia have in their Preambles ethical Amerindian principles that set the tone for their following paragraphs. The question now is: could concepts like that of Mother Nature or Good Life, originating from a pre-capitalist way of life, form a valid basis for a new hybrid form of neo-indigenous liberalism? Or are they to be considered an intermediate stage towards a new political and economic system? A soft relativism could resolve that impasse, by recognizing that there never existed a human society that lived in perfect harmony with its environment. ${ }^{23}$

In modern liberal societies, the notion of what makes a good life has become more and more vague. Differently, in Amazonia this notion exists in a manner that is linked to what the Brazilian anthropologist Viveiros de Castro called "Moral Economy of Intimacy". Gordon (p. 96) points to the link between wellbeing and a certain grade of diversification in all levels of social life, as happens among the Mebêngôkre, in Brazil. In this tribe, wellbeing corresponds to avoiding regulating social life according to a single dominating parameter. Practical paradigms like that can be found elsewhere in Amazonia: "buena vida" and "vivir bien" are core ethical norms among the Airo Pai, in Northern Peru, as revealed by Belaunde (2001). Amazonian natives, thus, combine classical Western values (such as friendship, free personal relations, lack of coercion, egalitarianism) with others that are rather autochthonic. Among them, there are also some which can be found in branches of Western Romanticism, such as longing for peace, nobility of character, affectivity, emphasis on kinship, on sharing and on giving, tendency to informality and a strong estimation of aesthetical elements in social life (GORDON, 97). The diversification of social life among the Mebêngôkre, as described above, is analogous to the current evolution of Western society towards complexity. The indigenous principles that have been included in the above mentioned constitutions are an expression of this trend. Complexity is understood nowadays as a characteristic of social systems in which the accumulation of gradual changes leads to another original but not arbitrary structure, whose roots are to be found in the ecological and social heritage bestowed by the former generations. ${ }^{24}$ Recognizing culture as a process and the judicial structure of liberal society as a part of this process implies the accommodation of contradictory interests) (see Taks, 341). Such accommodation implies an increase in complexity within a single group as well as among different groups. The whole process of renewing and recovering Amerindian Ethics can be considered a struggle for "a citizenship with the right to difference" 25 within a multinational state. In Canada, the Supreme Court resolved in 1991: "The accommodation of the differences makes the core of true equalitarianism" 26 . Complexity, for its part, must be understood as the

\footnotetext{
${ }^{22}$ HORKHEIMER, Max: Eclipse of Reason. New York, Oxford University Press, 1947, p. 107.

${ }^{23}$ FOLADORI and TAKS, p. 335.

${ }^{24}$ Idem, p. 336.

${ }^{25}$ LEÓN apud ALTMANN (2014).

${ }^{26}$ Apud KIMLICKA, 152.
} 
opposite of the traditional ideal of integrating native people into the dominant society. Complexity can be achieved by exchanging and permeating different levels of ethical benchmarks.

In its most general sense, buen vivir denotes, organizes, and constructs a system of knowledge and living based on the communion of humans and nature and on the spatial-temporal harmonious totality of existence. That is, on the necessary interrelation of beings, knowledges, logics, and rationalities of thought, action, existence, and living. This notion is part and parcel of the cosmovision, cosmology, or philosophy of the indigenous peoples of Abya Yala. $^{27}$

The Latin American concept of Good Life tends to eliminate the separation between nature and culture: according to it, a community includes its environment. That perception overcomes civilization's contradiction pointed to by Herbert Marcuse in his book Eros and Civilization. Marcuse developed Sigmund Freud's Civilization and its Discontents' argument, according to which Western civilization was enabled only by the repression of its erotic creative nature. Marcuse's recommendation in order to cure society's illness was the recovering of the aesthetic dimension of human life.

It is important to stress that discussing the contribution of indigenous ethics to the current environmental debate has nothing to do with the romantic creed of a harmonic relationship between primitive man and nature. Firstly, such an approach takes all preindustrial societies as equals, and secondly assumes that primitive societies possessed a high grade of consciousness about the implications of their actions to the environment, two assumptions that are wrong. ${ }^{28}$

Criticism of Romanticism doesn't necessarily mean discarding indigenous Ethics and their traditional practices. Foladori and Taks (2004) point out that collective ownership of natural resources doesn't lead to a negligent or predatory attitude towards the environment. That thinking stems from the belief that Capitalism would be the only possible social system. In a private property system, the public spaces tend to be utilized for private goals, since that is the logic of the dominant production system. However, when it comes to a collective appropriation of resources, they don't necessarily degrade. This is an example of the false contradiction between capitalist and non-capitalist society. ${ }^{29}$

Both models - the positivistic and the perspectivistic - have pros and cons; depending on how they are understood. In the first scenario, critics claim that the inclusion of indigenous ethical values at this moment - within an almost completely integrated world economy - would merely support the continuance of a spoiled social system. This censure refers to Capitalism, whose distorted Latin American breed had a most plundering nature. The new constitutions, with their ethic and bionomic concepts, enable a 'new stage' of Latin American economics, instead of renewing it groundly.

\footnotetext{
27 WALSH apud ALTMANN (2014).

28 The Sioux environmental spirituality goes along with an extremely carnivorous diet, just as the Hindu vegetarianism occurs in a society that is scarred by hideous poverty and environmental disequilibrium. ELLEN apud FOLADORI and TAKS, p. 327.

${ }^{29}$ Idem.
} 
The try to conciliate Capitalism and ecobiotic values is not new in that region. In 1978, Brazil proposed the Amazonian Cooperation Pact, which has been soon signed and ratified by eight South American states. It can be seen as an answer to the document The Limits to Growth, from the Stockholm Conference from 1972, which criticized the development model applied by third world countries, which emulated that of rich states of the Northern hemisphere. Aligned to the Club of Rome neo-Malthusian's worldview, the UN document pledged for a lessening of the periphery countries' industrialization, in order to spare the environment.

Some initiatives alerted the Amazonian states to the risk of an internationalization of the region, among them can be highlighted the International Institute of the Amazonian Rain Forest, sponsored by the UNESCO in 1948 and the Herman Kahn project, backed by the Hudson Institute (USA), of creating large artificial lakes to stir electricity generation and transport in the region. The Amazonian Pact presented counterproposals to those projects; its basic paradigm was the conciliation of industrial development and care for the rain forest's ecosystem. ${ }^{30}$

A Bolivian law from 1966 introduced already regulatory marks of the civil life that originate from the indigenous tradition. In the 2-C:

The Bolivian state doesn't recognize large land properties. Communitarian properties and private cooperatives have their existence guaranteed by the state. ${ }^{31}$

That ideal back to the Incas' aillus, which were originally little land acres administered according to three concentric authority spheres, namely (1) family; (2) community and (3) nation. Currently, the indigenous lands are once again organized following such tradition. That paradigm includes the challa, an Aymará ceremony that mixes feast, old Inca rites and carnival. That kind of tradition carries on original South American symbolism; to include it in the constitution expresses the equivalence of the individual rights - minorities comprised - and of those which concern the protection to the nature. The land administration has its counterpart also in three concentric spheres: rules that are for (1) family norms; (2) social norms and (3) legal norms.

Instead of a hierarchic system, it operates based in equivalence and perspectivism, regarding especially the human rights of third generation, which are considered solidarity rights, since they can be exerted only by groups or collectivities.

\section{Other Eubiotic Principles}

The following lines have evident ties to the classical Aristotelian virtues. However, shall be always regarded that the ancient Greek Ethics emerged in a completely different context. Hence, occasional traces of metaphysical thinking that could be

\footnotetext{
${ }^{30}$ As the Amazonian Cooperation Pact was signed, there were already a strong economic activity in that region, claiming for a new model of relationship between progress and preservation of nature: Ecuador and Peru discovered recently oil in the jungle; Venezuela was constructing the Guri Dam Hydroelectricity (the second in the world at that time, after Itaipú); in Bolivia, the Amazonian region (Santa Cruz de la Sierra) had a way stronger economic activity than La Paz or Potosí; Suriname and Guyana were drafting big projects to industrialize aluminum.

${ }^{31} \mathrm{http}: / / \mathrm{www}$.oas.org/juridico/mla/sp/bol/sp bol-int-text-const.html
} 
detected in the Andean wordings shall be understood just in relation to their specific Amerindian cosmology, i.e. free from the Hellenic transcendence ideal. ${ }^{32}$

- Ayni: sense of solidarity with the family and the group. It concerns specific tasks that shall be accomplished with the help of two or more family groups.

- Maki purarina: the reciprocity (maki: hand + purarina: to tend). A kind of comportment that shall be observed by members of a community regarding their relatives and neighbors. It reinforces the communication levels among people; it makes people know better each other and the mutual recognizing as mankind.

- Yanaparina: solidarity as a founding value of life. The historical development of the Andean communities did reinforce the ties among the groups, aiming to master difficulties that were too big in order to be solved by a single tribe.

- Pakta kausay: the balance of power between individual, family and collectivity - everyone has a say in the group; individuals can go different as prescribed by majority. It regards as well as the emotional equilibrium that has $\mathrm{t}$ be achieved by each person.

- Alli kausay: the harmony. It concerns the over spilling power of virtues; a single virtuous individual can shed good influence over the larger circles of coexistence, namely the family and the community.

- Wiñak kausay: creativity. It corresponds to the unstoppable search for innovation. There is a constant conflict between the existing world and that which is steadily recreated. Such friction points to the overcoming of the old.

- Samak kausay: serenity. It recalls the feeling of peace transmitted by the horizon line and the water line of the lakes in order to create a psychological condition that aims to dam thoughtless actions. It encompasses body actions, like deep breathing, in order to calm down and gain distance from severe affections.

- Runakay: the knowledge of how to be (runa: person, human). It is a sort of sum of all anterior concepts. It synthesizes the self accomplishment of each human being, a gift that can be only achieved through mastering all values above.

\section{Conclusion}

The multiplication of jurisdictional levels and the creation of new subjects of rights led to frictions. It is the case of animals and environment: recognizing them as subjects of rights affronts the classical conception of subjective rights ${ }^{33}$. The frictions recently

\footnotetext{
${ }^{32}$ A more detailed list and description can be seen in KOWII, Ariruma: El Sumak Kawasay.

${ }^{33}$ As for inanimate objects as parties in litigation, there were antecedents in the USA (1972): The critical question of "standing" would be simplified and also put neatly in focus if we fashioned a federal rule that allowed environmental issues to be litigated before federal agencies or federal courts in the name of the inanimate object about to be despoiled, defaced, or invaded by roads and bulldozers and where injury is the subject of public outrage. Contemporary public concern for protecting nature's ecological equilibrium should lead to the conferral of standing upon environmental objects to sue for their own preservation. This suit would therefore be more properly labeled as Mineral King v. Morton.
} 
arisen in those matters are difficult to settle. It is anyway difficult to resolve the conflict between federalism and cultural identity in countries with serious historical social deficit. In order to settle social discrepancies, it would be necessary a state whose actions contemplate to act in favor of a not totally equalitarian federalism. The search for such asymmetrical federalism ${ }^{34}$ is all the more difficult in the Latin American case, a continent that has been traditionally strongly centralized. The presidential system there was historically the expression of the political tendencies of the criolla society of excluding the indigenous minorities from the decisional instances ${ }^{35}$.

The clash of paradigms appears to be inevitable, in a first moment. On one hand, cases like that of the Ecuadorian Yasuni-Ishpingo, Tambococha, and Tiputini (ITT) Initiative, referring to the corridor of oil reserves within the Yasuni National Park, recognized as first post-oil development initiative that the benefits gained from the Amazon are greater than the economic benefits from oil extraction. ${ }^{36}$ On the other hand, there are concerns that the Rights of Nature could negatively affect foreign direct investment, since companies will not want to comply with the more stringent regulations. A social equilibrium may be very difficult to achieve. It seems that trying to favor a group make others worse off, a problem studied by the Italian economist Vilfrido Pareto, in the nowadays known as the Pareto efficiency, or Pareto optimality. The allocation of resources, thus, will depend on a consensus between the involved groups. Apparently, Pareto's system for social equilibrium could be possible, at least mathematically, in an ideal case. The new Latin American constitutions, although, will need probably more time in order to accommodate tensions within their societies.

The core question is to determine which concrete demands can be granted in those countries. Since law is a science that expresses itself in words, the concession made to indigenous communities to express their laws in their language is an important step which has been done, for instance, in Peru. In Ecuador and Paraguay the comparison of languages is valid: besides Spanish, Guarani, Quechua, Shuar and "all ancestral

[...]Inanimate objects are sometimes parties in litigation. A ship has a legal personality, a fiction found useful for maritime purposes. The corporation sole - a creature of ecclesiastical law-is an acceptable adversary and large fortunes ride on its cases... So it should be as respects valleys, alpine meadows, rivers, lakes, estuaries, beaches, ridges, groves of trees, swampland, or even air that feels the destructive pressures of modern technology and modern life. The river, for example, is the living symbol of all the life it sustains or nourishes-fish, aquatic insects, water ouzels, otter, fisher, deer, elk, bear, and all other animals, including man, who are dependent on it or who enjoy it for its sight, its sound, or its life. The river as plaintiff speaks for the ecological unit of life that is part of it. https://supreme.justia.com/cases/federal/us/405/727/case.html. In 2012, New Zealand's Whanganui River was legally declared a person with standing (via guardians) to bring legal actions to protect its interests. http://www.nzherald.co.nz/nz/news/article.cfm?c id=1\&objectid=10830586

${ }^{34}$ See KIMLICKA, p. 48-9.

35 The word criollo was the denomination which has been given, in the colonial times of Latin America, to Spaniard's sons and daughters who were born in the New World and compromised with the metropole's cultural and political values.

36 Altmann (2014) affirms the very revival of the Sumak Kawsay concept aimed to fight petroleum exploitation in indigenous territories: The Ecuadorian indigenous movement has developed the concept of Good Life (Sumak Kawsay or Buen Vivir) as a conceptual weapon in order to defend the territories of indigenous nationalities as the movement itself defines them. Starting in 2002, petroleum exploitation in indigenous areas in the Amazon has been denounced as an attack against the principles of the traditional concept of Good Life. 
languages" are accepted for official documents ${ }^{37}$. However, only in Peru is each citizen allowed the use of an interpreter in the presence of any state representative: "todo peruano tiene derecho a usar su propio idioma ante cualquier autoridad mediante un intérprete." 38

Regarding egalitarianism, one problem that still awaits a solution is that of the affiliation to ethnic groups. In order to determine it, the cultural criteria are more important than any other factor. In Bolivia, $62 \%$ of the population claim to be descendents of the original inhabitants. The criteria are the same as adopted in Brazil to recognize people who descended from African slaves. In both Brazil and Bolivia one who declares oneself as belonging to a determined ethnic or social group will be thus officially recognized.

Additionally, there are some questions that are worth pointing out regarding the future of the Latin American constitutions. The contribution of the Latin American perspective to the environmental debate has potential to continue to evolve, if some issues such as the following are sufficiently discussed:

1. How to divide a property of a state into several juridical zones in order to resist moneyed concerns, a historical problem in Latin America.

2. How to discuss social inclusion of groups of indigenous peoples and mestizos without stigmatizing the Spanish colonial heritage, which could provoke the political schism of the state.

3. How to bring together the concession of privileges to the landed population with the fragile economical and social standard of the city residents, who can hardly express their wishes for more autonomy without being accused of separatism by the central administration (particularly in Bolivia).

4. How to respond convincingly to the criticism that equalizing all 36 Bolivian ethnic groups could lead to the state's disaggregation. A similar problem contributed to weaken national unity in the former Soviet Union.

Finally, the new legal benchmarks must serve inclusion, and not seclusion nor the replacement of the old hierarchy by a new one. Latin America's future and the answers for its ecological questions will depend on the ability to balance egalitarianism with diversity.

\footnotetext{
${ }^{37}$ Constitución de Ecuador, artículo 1.

${ }^{38}$ Constitución Política de Perú, artículo 2.
} 


\section{Bibliography}

ADORNO, Theodore: Minima Moralia - Reflections from Damaged Life. http://members.efn.org/ dredmond/MM2.html

ALTMANN, Philipp: Good Life As a Social Movement Proposal for Natural Resource Use: The Indigenous Movement in Ecuador in Consilience: The Journal of Sustainable Development.

http://www.consiliencejournal.org/index.php/consilience/article/viewFile/340/195

ARISTOTLE, also David Ross, Lesley Brown (1980). "The Nicomachean Ethics". Oxford University Press. Retrieved 2010-06-05.

CONSTITUCIÓN POLÍTICA DE LA REPÚBLICA DE ECUADOR http://www.ecuanex.net.ec/constitucion/

CONSTITUCIÓN POLÍTICA DEL PERÚ http://www2.congreso.gob.pe/sicr/RelatAgenda/constitucion.nsf/constitucion

FOLADORI, Guillermo and TAKS, Javier: Um olhar antropológico sobre a questão ambiental in MANA 10(2) 323-348. 2004.

http://www.scielo.br/pdf/mana/v10n2/25163.pdf

GACETA OFICIAL DE BOLIVIA: Decreto Supremo No.1696.

http://ucordillera.edu.bo/jdownloads/BoletinesComunicados/decreto1696.pdf

GORDON Cesar: Bem Viver e propriedade: o problema da diferenciação entre os Xikrin-Mebêngôkre (Kaypó) in MANA 20(1), 95-134, 2014.

HORKHEIMER, Max: Eclipse of Reason. New York, Oxford University Press, 1947

Indigenous Peoples, Democracy and Political Participation, in Political Database of the Americas. http://pdba.georgetown.edu/IndigenousPeoples/introduction.html

INTERNATIONAL COVENANT ON CIVIL AND POLITICAL RIGHTS https://treaties.un.org/doc/Publication/UNTS/Volume\%20999/volume-999-I-14668English.pdf

JONAS, Wolf: Towards Post Liberal Democracy in Latin America? A Conceptual Framework Applied to Bolivia in Journal of Latin American Studies. http://journals.cambridge.org/action/displayAbstract?fromPage $=$ online $\&$ aid $=8854270 \&$ fileId=S0022216X12000843

JUSTIA US SUPREME COURT: Sierra Club v. Morton 405 U.S. 727 (1972), https://supreme.justia.com/cases/federal/us/405/727/case.html

KIMLICKA, Will: Ciudadanía multicultural. Barcelona, Paidós, 1996. 
KOWII, Ariruma: El Sumak Kawasay.

http://www.un.org/esa/socdev/unpfii/documents/El\%20Sumak\%20Kawsay-

ArirumaKowii.pdf

LAMBERT, Renaud: O espírito de Pachamama, em Le Monde Diplomatique Brasil.

São Paulo: Instituto Pólis, Nr. 43, fevereiro de 2001

LEY CORTA DE DERECHOS DE LA MADRE TIERRA.

http://www.ftierra.org/ft/index.php?option=com_content\&view=article\&id=4288:rair\& catid=152: cc\&Itemid=210

NUEVA CONSTITUCIÓN POLÍTICA DEL ESTADO.

http://www.patrianueva.bo/constitucion/

RADIN, Paul: Primitive Man as Philosopher. New York: D. Appleton \& Company, 1927.

SBARDELOTTO, Moisés: Sumak Kawsay: uma forma alternativa de resistência e mobilização. IHU, Revista do Instituto Humanitas Unisinos.

http://www.ihuonline.unisinos.br/index.php?option=com_content\&view=article\&id=34 $\underline{36 \& \text { secao }=340}$

: O bem-viver como perspectiva ecobiótica e cosmogônica.

IHU Revista do Instituto Humanitas Unisinos.

http://www.ihuonline.unisinos.br/index.php?option=com_content\&view=article\&id=34 $\underline{46 \& \text { secao }=340}$

SINGER, Peter: Practical Ethics. New York, Cambridge University Press, 1979

SHUTTLEWORTH, Kate: Agreement entitles Whanganui River to legal identity in THE NEW ZEALAND HERALD.

http://www.nzherald.co.nz/nz/news/article.cfm?c_id=1\&objectid=10830586

UNITED NATIONS DECLARATION ON THE RIGHTS OF INDIGENOUS

PEOPLES, http://www.un.org/esa/socdev/unpfii/en/drip.html

UNITED NATIONS, International Covenant on Civil and Political Rights.

https://treaties.un.org/doc/Publication/UNTS/Volume\%20999/volume-999-I-14668-

English.pdf 
